\title{
THE EFFECT OF SERVICE QUALITY ON CUSTOMER LOYALTY OF GENERATION Y - AN EMPIRICAL INVESTIGATION ON SUPERSTORES IN BANGLADESH
}

\author{
MIRZA MOHAMMAD DIDARUL ALAM* \\ Othman Yeop Abdullah Graduate School of Business (OYAGSB) \\ Universiti Utara Malaysia \\ \& \\ School of Business \& Economics \\ United International University, Bangladesh \\ E-mail:mirza@bus.uiu.ac.bd \\ *Corresponding Author: mirza@bus.uiu.ac.bd
}

\begin{abstract}
Today, retailers have been struggling to retain their existing customers in the face of severe competition in their business operations. By expanding the service quality, retailers will be able to stand out among the other businesses and create the opportunity to strengthen customer loyalty, particularly within the younger generation. The aim of this study is to propose and empirically investigate the mechanism of increasing customer loyalty of Generation $Y(G e n Y)$ toward superstores by means of enhancing service quality practices. Based on a structured questionnaire, data was collected from 252 Gen $Y$ consumers who have visited four leading superstores in Bangladesh. The data was analyzed through SEMPLS3.0 to test the validity of the measures, and used to examine the hypothesized relationships by employing structural equation modeling. The findings show that the Retail Service Quality Scale (RSQS) is a reliable and valid instrument for assessing service quality in the retail sector of Bangladesh. The structural model indicates that the customer loyalty of Gen Y toward superstores is positively influenced by retail service quality dimensions such as policy, reliability, personal interaction, physical aspect, and problem solving, in the order of influencing strength. This paper provides the research implications and avenue for future research.
\end{abstract}

Keywords: Service quality, RSQS, Customer loyalty, Generation Y, Superstore.

Received: $10 / 2 / 2018$

Revised: $16 / 10 / 2018$

\section{Introduction}

There has been a paradigm shift with regards to the shopping behavior of customers, as they have started to frequently visit organized retail stores, such as superstores, rather than "mom and pop stores" (Jain \& Aggarwal, 2018). Around the world, customers have become more informed, conscious, and sophisticated due to the increase in disposable income, better expectancy to lead a standard life, greater participation of women in
Accepted: 31/12/2018

Published: 14/7/2019 the workforce, rapid urbanization, and the rise of younger cohorts within the population (Shamsher, 2016). Due to the changing nature of customers toward shopping and the increasing expectations from service providers, managing better service quality has become a crucial task for retailers (Vargo \& Lusch, 2004). Hence, facing situations whereby the scope for differentiation has become limited for retailers, it is therefore paramount that they provide excellent service quality to build and expand their loyal customer base. (Jain \& Aggarwal, 2018). 
In the retail sector, enhancing service quality has become a prime strategy for retailers to retain their customers and stand out from the rest of the competition (Prentice, Wang, \& Lin, 2018; Sivapalan \& Jebarajakirthy, 2017). Moreover, maintaining customer loyalty has been vital for retailers as they have experienced customer decline (Maggioni, 2016) by fierce competition (Adam, Tengeh, \& Cupido, 2018; Hegner-Kakar, Richter, \& Ringle, 2018) through the noticeable changes in the global retail landscape (MohdRamly \& Omar, 2017). This decreasing trend is most noticeable in developing countries (Grosso, Castaldo, \& Grewal, 2018), like Bangladesh. Furthermore, retailers have been required to concentrate more efforts on drawing customers from Generation Y (Gen Y) as they have the tendency to exhibit less loyalty towards products/ brands/retailers (Parment, 2013; Quintal, Phau, Sims, \& Cheah, 2016) and are prone to switch between competitors (Chuah, Marimuthu, Kandampully, \& Bilgihan, 2017).

Therefore, this study attempts to examine the influence of service quality on customer loyalty of Gen Y in the context of retail superstores in Bangladesh. Literature has indicated that most service quality models have been formulated and validated in Europe and North America (Brady \& Cronin, 2001; Dabholkar, Thorpe, \& Rentz, 1996; Grönroos, 1984; Parasuraman, Zeithaml, \& Berry, 1988). Hence, this study seeks to understand the applicability of the models, in the context of Asia (Gong \& Yi, 2018).

In measuring service quality in the retail context, Dabholkar et al. (1996) developed and tested the validity of a five-factor hierarchical instrument, namely the Retail Service Quality Scale (RSQS), in the context of America, by taking into consideration that retailing encompasses both tangible goods and intangible services. Though the scale was implemented and further validated in both developed and developing countries such as India, Kazakhstan, Malaysia, South Africa, Sri Lanka, and Vietnam (Bhat, 2016; Boshoff \&
Terblanche, 1997; Das, Kumar, \& Saha, 2010; Deb \& Lomo-David, 2014; Jain \& Aggarwal, 2016; Nguyen, Nguyen, Cao, \& Phan, 2016; Sivapalan \& Jebarajakirthy, 2017; Yeap Ai Leen \& Ramayah, 2011), this study is limited to the retailing context of Bangladesh. Moreover, past studies that focuses on the application of the Retail Service Quality Scale (RSQS), by addressing a particular generational cohort (like Gen Y) irrespective of country and culture are rare. Therefore, to fill these gaps in literature, this study examines the impact of service quality dimensions (RSQS) over loyalty of Gen Y in the context of retail superstores in Bangladesh.

\section{Literature Review}

\section{Superstore Retailing in Bangladesh}

A superstore (or supermarket) can be defined as a self-service store organized with various departments to offer a wide range of food and household merchandises, typically larger than a grocery store but smaller than a hypermarket (Ushantha, Wijeratne, \& Achchuthan, 2014). These stores are basically located near residential areas as well as in key urban centrals (Amorim \& Bashashi Saghezchi, 2014).

In developing countries, the diffusion of supermarkets got off the ground in three waves, beginning from the early 1990s (Bachmann, 2008; Monthly Business Review, 2017). The first wave hit Latin America, East Asia (excluding China), and South Africa; the second wave (mid-to-late 1990s) happened in Southeast Asia (excluding Vietnam), Mexico, and Central America; whereas, countries like China, Vietnam, and India were part of the third wave of diffusion (late 1990s to early 2000s). Bangladesh is part of the fourth wave of diffusion (Reardon, Timmer, \& Berdegue, 2004) through the commencement of superstore "Agora" in 2001.

Although the initial growth of the supermarket industry in Bangladesh was slow, it has began 
to gain momentum over the course of its introduction. According to industry experts, it is expected that by the year 2021, the turnover from the industry will amount to $\$ 2.6$ billion, with an estimated 30 percent annual growth of sales (Gain Report, 2013). Currently, the superstore retailing industry of Bangladesh comprises of 121 outlets (Monthly Business Review, 2017) and the majority of them are being managed by four leading operators, namely Agora, Meenabazar, Pricebazar, and Shwapno. The entire retail industry contributed 41 percent to the country's Gross Domestic Product (GDP) and has lowered the unemployment rate by accommodating about 20 percent of the labor force in Bangladesh (The Daily Star, 2016). In addition, the superstore industry has played a significant role in excelling job opportunities by accommodating a minimum of fifty workers in a single outlet (Arif, 2013).

\section{Generation $Y$}

In 1927, German sociologist Karl Mannheim introduced the notion of "Generation" in his seminal work (Alwin \& McCammon, 2003). Later, Inglehart (1977) introduced the 'Generational Cohort Theory' to segregate the total population into different groups (cohorts) to gain a better understanding of their behavioral characteristics (Lissitsa \& Kol, 2016). As one of the generational cohorts identified in literature, Gen Y has been of extreme importance to today's marketers. Individuals born in the years between 1977 and 1994 are considered members of Gen Y (Cham, Ng, Lim, \& Cheng, 2018; Dalla Pozza, Heitz-Spahn, \& Texier, 2017). Despite the disagreements between researchers on the discrepancy with respect to the starting and ending period of Gen Y cohorts, such variation is still tolerable due to the dissimilarities among countries and societies (Soares, Zhang, Proença, \& Kandampully, 2017). About 2 billion people in the world belong to the Gen Y cohort, representing one third of the world population (Tangsupwattana \& Liu, 2017); whereby, the size of this cohort in Asia is about 660 million
(Sundarapandiyan, Duraiarasi, Babu, \& Prabakaran, 2015).

Consistent with the ratio of the world population, about 51.89 million (33.22 percent) of the population of Bangladesh represent this young cohort (CIA, 2017). Due to their sheer number and high spending capacity, this cohort has become a pivotal market segment to be considered by the marketers (Bilgihan, 2016), specifically for retailers (Altinbasak-Farina, \& Guleryuz-Turkel, 2015). They have an affinity to technology (Chahal \& Rani, 2017) and are influential to the market (Knittel, Beurer, \& Berndt, 2016) due to their active presence in social media (Soares et al., 2017). Moreover, the Gen Y cohort is less reactive to price but more sensitive to the quality and style compared to earlier generations when conducting purchases (Fyall, Leask, Barron, \& Ladkin, 2017).

\section{Theoretical Support}

This study attempts to justify empirically the influence of service quality on customer loyalty of Gen $\mathrm{Y}$ in the retail setup. The proposed relationship for the construct of this study is grounded on the theory of Cognitive-MotivationRelational (CMR) proposed by Lazarus (1991). The underlying assumption of this theory is to comprehend the correlation between cognitive assessment and emotional motivation. Based on the evaluation of the environment that is grounded on values and beliefs, individuals will form cognitive biases that would trigger emotional responses toward environmental factors. As a consequence, these emotions will help strengthen the enduring relationship between the environmental aspects.

Based on the assumption of the CMR theory, it is reasonable to examine the relationship between service quality and customer loyalty in the context of retailing, as suggested by numerous scholars (such as Brady \& Robertson, 2001; Sivapalan \& Jebarajakirthy, 2017). By 
proposing a model explaining the association of service quality with customer responses (such as, customer satisfaction and purchase intention), Brady and Robertson (2001) applied the theory of CMR. Based on their assumption, service quality was considered as the basis of customers' cognitive evaluation, whereas their responses (in terms of satisfaction and purchase intention) are to be considered as emotional motivations. Furthermore, Sivapalan and Jebarajakirthy (2017) applied the CMR theory to justify the relationship between the dimensions of retail store service quality and customer loyalty. Consequently, the proposed conceptual framework of this study will be based on the CMR theory.

\section{Customer Loyalty}

Customer loyalty is a vital behavioral outcome, for which service organizations have been struggling to achieve (El-Adly, 2018). Due to its massive influence on an organization's profitability, customer loyalty has been considered as the 'holy grail' of marketing (Lee, Tang, Yip, \& Sharma, 2018) and has become a focal point in service marketing literature (Nyadzayo \& Khajehzadeh, 2016). Although the importance of this construct has been widely studied in past marketing literature (Makanyeza \& Chikazhe, 2017), a universal definition of customer loyalty has yet to be resolved (Ngobo, 2017). According to Oliver (1999), loyalty is “a deeply held commitment to rebuy or repatronize a preferred product or service consistently in the future, thereby causing repetitive same-brand or same brand-set purchasing, despite situational influences and marketing efforts having the potential to cause switching behavior" (p. 34). However, this definition has been widely criticized on the grounds of its behavioral focus. In addition, measuring loyalty based on attitudinal perspective has been criticized in literature, wherein psychological attachment may not necessarily result into actual behavior (Kamran-Disfani, Mantrala, Izquierdo-Yusta, \& Martínez-Ruiz, 2017).
Past studies have indicated that true reflation of loyalty can only be achieved by incorporating both behavioral and psychological perspectives (Bapat, 2017; de Leaniz, \& del Bosque Rodríguez, 2016). This integration is important for retailers due to its unique characteristics that prevail in the retail setup (Dick \& Basu, 1994; Sivapalan \& Jebarajakirthy, 2017). This paper emphasizes the study of loyalty from the composite perspective (both attitude and behavior), with the focus of analyzing customer loyalty of Gen Y in superstore retailing.

\section{Service Quality Models}

The conceptualization of service quality varies between scholars, however the alternative approaches of such conceptualization has been clustered in two basic categories namely, expectancy disconfirmation paradigm and performance only measure (Li, Yu, Pei, Zhao, \& Tian, 2017). Under the disconfirmation paradigm, scholars further classified service quality into two different schools of thought: Nordic or European model and American model (Jain \& Aggarwal, 2018). The Nordic model was introduced by Gronroos (1984), and viewed service quality in terms of technical quality (also known as outcome quality) and functional quality (also known as process quality) (Kasiri, Cheng, Sambasivan, \& Sidin, 2017). Under the American model, the conceptualization of service quality was initiated by Parasuraman, Zeithaml, and Berry (1985) through the identification of ten key determinants. The model was further refined by Parasuraman et al. (1988) and was clustered into five dimensions which are reliability, responsiveness, assurance, empathy, and tangibles. They measured service quality as the gap between perceptions and expectations (GAP 5 of the initial model) of customers with regards to the 22 items that were factored into the five dimensions, which became known as the SERVQUAL model.

Although the SERVQUAL model has been extensively applied in numerous service sectors 
to measure service quality, its application has been criticized by numerous scholars based on issues such as inadequacy in conceptualization and operationalization (Carman, 1990; Cronin \& Taylor, 1992), issue on scale applicability in a wider range of service industries (Babakus \& Boller, 1992; Carman, 1990), high chance of misinterpretation due to the length of questionnaire (Bouman \& Van der Wiele, 1992; Siu \& Cheung, 2001), and contextual limitations in the scope of the scale (Dabholkar et al., 1996).

Conversely, by incorporating the performance only measure approach, scholars have tried to measure service quality based on the perception of the customers while disregarding their expectations (Brady \& Cronin, 2001; Cronin \& Taylor, 1992; Dabholkar et al., 1996). Based on the study of the limitations of the SERVQUAL with respect to its theoretical, methodological, and empirical aspect, Cronin and Taylor (1992) developed and established the SERVPERF scale, which essentially became a better measure over the Gap model. Subsequently, several scholars developed numerous scales based upon the perception only measure approach, such as the Retail Service Quality Scale (RSQS) by Dabholkar et al. (1996), and multi-dimensional and hierarchical model, by Brady and Cronin (2001), etc.

\section{Retail Service Quality}

Parasuraman et al. (1988) defined the term "service quality" in their seminal work as a "global judgment or attitude relating to the overall excellence or superiority of the service". This conceptualization of service quality was proposed to incorporate the domain of service quality in general, however, it is inapplicable in the context of retailing (Dabholkar et al., 1996; Gagliano \& Hathcote, 1994). Unlike pure services (such as education), retail service quality is different due to its hybrid nature, as it comprises both physical goods and intangible services (Kajenthiran, 2018; Sivapalan \& Jebarajakirthy, 2017).

Table 1

Five Basic Dimensions of RSQS

\begin{tabular}{ll}
\hline Dimension & Description \\
\hline Physical Aspect & Store layout in terms of appearance and convenience. \\
Reliability & Delivering as promised by the retailers and doing things right towards customer. \\
Problem Solving & $\begin{array}{l}\text { Store staff's capability to manage customers' problems, complaints, returns, and } \\
\text { exchanges. }\end{array}$ \\
Policy & $\begin{array}{l}\text { A set of general guiding rules regarding merchandise quality, credit card facilities, } \\
\text { parking facilities, and suitable store operating hours. }\end{array}$ \\
Personal Interaction & $\begin{array}{l}\text { Skills of store personnel to become courteous, helpful and their ability to instill trust } \\
\text { and confidence in customers. }\end{array}$ \\
\hline
\end{tabular}

Source: Dabholkar et al. (1996). 
Initially, several scholars have tried to measure service quality in the retail setup by deploying the SERVQUAL model (such as Carman, 1990; Finn \& Lamb, 1991; Gagliano \& Hathcote, 1994), but scholars realized that a dedicated measurement instrument is essential to capture the retail service quality effectively. In this connection, by applying a triangulation approach, Dabholkar et al. (1996) conducted a study to generate a distinct instrument to evaluate service quality in the retail setup. Based on the outcome of their study, they developed and validated a hierarchical model namely, the Retail Service Quality Scale (RSQS) which is comprised of 28 items (17 from SERVQUAL model and 11 from their qualitative study) and are clustered into five basic dimensions (Table 1). This instrument has been widely applied by several researchers to capture service quality in various store formats and culture (such as Bhat, 2016; Kim \& Jin, 2002; Siu, \& Cheung, 2001; Wong \& Sohal, 2003; Yeap Ai Leen \& Ramayah, 2011).

\section{Physical Aspect and Customer Loyalty}

From a broad perspective, physical aspect of a superstore encompasses the appearance as well as convenience of the store. Specifically, it includes the physical facilities of the store, equipment available in the store, visual materials, and easy and convenient store layout (Dabholkar et al., 1996). Attractive store materials along with better store layout encourages customers to develop better attitude towards the store (Ha, Minh, Anh, \& Matsui, 2014; Singh, 2012; Wong \& Sohal, 2003). In the context of large retail chain stores in Northern Cyprus, Nadiri and Tümer (2009) found that in determining customers intention to buy and recommend, the physical aspect of the store played a significant role. Ha, Minh, Anh, and Matsui (2015) conducted a study in Vietnam on 664 supermarket shoppers and deduced that the relationship between physical aspect and customer loyalty was significantly positive.
Furthermore, by collecting data from 2,375 supermarket customers in Sri Lanka, Sivapalan and Jebarajakirthy (2017) examined the influence between retailers' information on dimensions of RSQS and customer loyalty. In their analysis, it is revealed that the linear relationship between physical aspect and customer loyalty was statistically significant. Based on these assumptions, we offer the following hypothesis:

H1 Physical aspect positively affects customer loyalty to superstores.

\section{Reliability and Customer Loyalty}

The reliability aspect of superstores indicate the extent by which retailers conduct themselves as promised, without failing their customers (Dabholkar et al., 1996; Vazquez, RodrılguezDel Bosque, Dilaz, \& Ruiz, 2001). Customers will likely prefer retail stores that continue to guarantee quality product and services without failure (Nadiri \& Tümer, 2009; Sivapalan \& Jebarajakirthy, 2017; Wong \& Sohal, 2003). Based on survey data from 447 customers in Hong Kong, Yuen and Chan (2010) investigated the effects of product and service quality of retail stores on two levels of customer loyalty (staff \& store). They asserted that the more the customers perceive the store as reliable, the more likely they will visit the store. Thus, we propose the following hypothesis:

\section{H2 Reliability exerts a positive influence on} customer loyalty to superstores.

\section{Problem Solving and Customer Loyalty}

The problem solving issue of service quality from a retailing perspective, points to the capacity of the stores to deal with potential problems from customers such as returns, complaints, and exchanges (Dabholkar et al., 1996; Deb \& Lomo-David, 2014; Jain \& Aggarwal, 2018). It 
is evident in literature that when problems are resolved, customers will develop a positive outlook and attitude towards the store, which in turn, increases customer visits (Caruana, 2002; Ha et al., 2015; Kajenthiran, 2018; Nadiri \& Tümer, 2009; Singh, 2012). Thus, it is expected that when complaints from customers are settled positively, they will exhibit more loyalty towards the store. Hence, we offer the following hypothesis:

H3 Problem solving positively affects customer loyalty to superstores.

\section{Policy and Customer Loyalty}

Policy refers to the guiding principles of a store with respect to the assortment of merchandising, credit card facilities, loyalty programs, suitable operating hours, and parking facilities (Dabholkar et al., 1996; Yuen \& Chan, 2010). Incorporating an effective retailing policy is paramount to attract and retain customers. Numerous studies have proven empirically that customers are more likely to visit a store with an effective guiding policy (Ha et al., 2015; Kajenthiran, 2018; Sivapalan \& Jebarajakirthy, 2017). In the context of retailing in India, Singh (2012) examined the relationship between the dimensions of retail store service quality and customer loyalty. The study revealed that retail policy has a positive and significant correlation towards customer loyalty. Therefore, based on the outcome from the foregoing literature, we propose the following hypothesis:

H4 Policy has a positive effect on customer loyalty to superstores.

\section{Personal Interaction and Customer Loyalty}

Personal interaction dimension of retail store service quality is the ability of store employees to interact with customers courteously and in a helpful manner, ultimately boosting trust and confidence among the customers (Dabholkar et al., 1996; Jain \& Aggarwal, 2018). In the service setting, the cumulative perception of customers is basically formed as a function of several service encounters in general or with the organizational staff of the stores. Staff interaction is vital for retail organizations. As more customers experience customized support and attention from the employees of the store, the greater the level of customer satisfaction and loyalty (Beneke, Hayworth, Hobson, \& Mia, 2012; Kajenthiran, 2018; Wong \& Sohal, 2003). In their study, Sivapalan and Jebarajakirthy (2017) empirically deduced that personal interaction has a direct and positive relationship in determining customer loyalty towards retail stores. Thus, we offer the following hypothesis:

H5 Personal interaction has a positive effect on customer loyalty to superstores.

\section{Conceptual Model}

Based on the above discussion and proposed hypotheses, this study developed a conceptual framework focusing on the relationship between the dimensions of retail store service quality and customer loyalty. This framework is grounded on the CMR theory which is shown in Figure 1. 


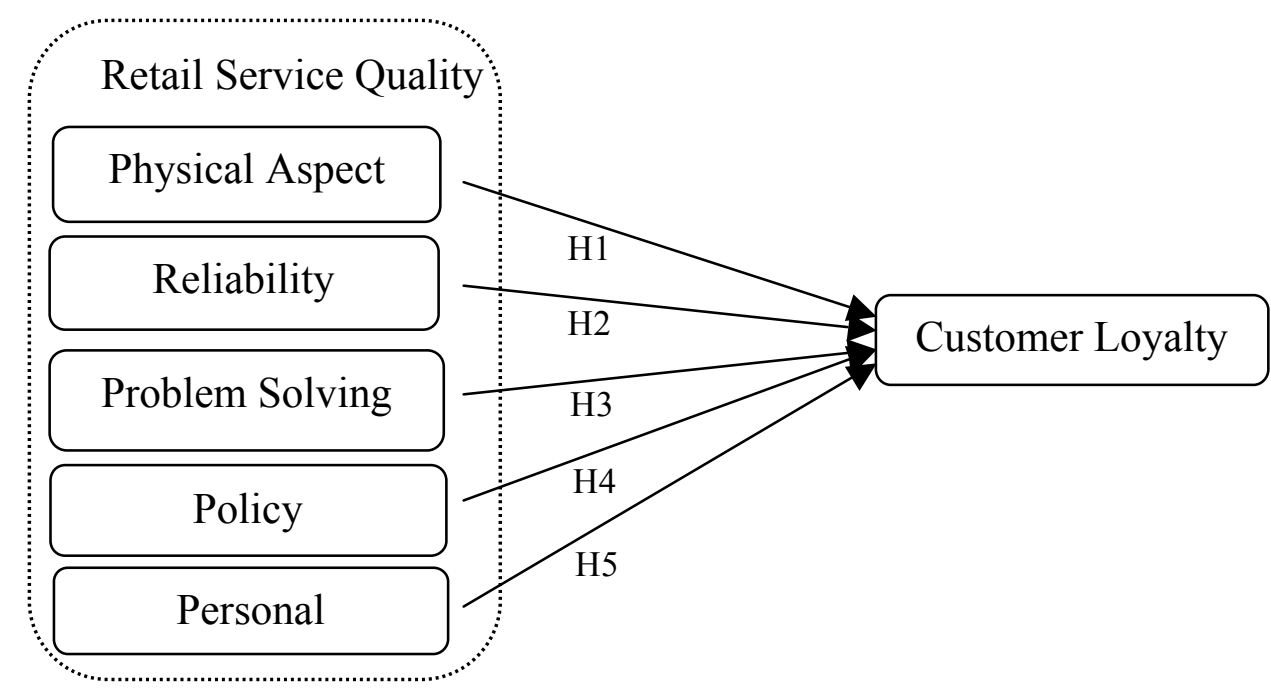

Figure 1. Conceptual Framework of the Study

\section{Methods}

The approach of this study is quantitative, with a structured questionnaire (Appendix - A) prepared and was used as a prime instrument for data collection.

The measurement items of service quality and customer loyalty were adapted from previous studies. To measure the service quality of superstores, the RSQS instrument developed by Dabholkar et al. (1996) was used with slight modifications. The original scale consisted of 28 items under five basic dimensions. However, due to contextual differences, four items were discarded from the final questionnaire, as suggested by Deb and Lomo-David (2014), and Meng, Summey, Herndon, and Kwong (2009). Five items for physical aspect, five for reliability, three for problem solving, three for policy, and eight for personal interaction dimension from the chosen scale were finally drawn. The six items to measure customer loyalty were adapted from Chang and Yeh (2017). All the items of the selected constructs were measured based on the five-point Likert scale starting from 1 = strongly disagree to $5=$ strongly agree. By consecutively translating the initial questionnaire between English and Bengali, clarity and preciseness of the converted items were enhanced and maintained throughout the study.

The study collected data from 252 Gen Y customers (age between 23 and 40 years inclusive) that visited four major superstores (e.g. Agora, Meenabazar, Princebazar, and Shwapno) in Dhaka (Capital of Bangladesh) and Chattagram city (Commercial Capital of Bagladesh). The collected data was then applied into a structural equation model, as suggested by Byrne (2010), and Marcoulides and Saunders (2006). Mall-intercept sampling technique was applied to the respondents systematically, in the absence of sampling frame. However, to ensure a holistic representation of the selected samples, data was collected at two different time slots; morning and evening of the sampling days during the tenure of four weeks for data 
collection, as recommended by Orel and Kara (2014).

\section{Data Analysis}

Initially, to examine and screen out the missing values, incomplete responses, identifying outliers from the data, as well as to analyze the demographic profile of the respondents, SPSS Version 23 was applied. Subsequently, Partial Least Square Structural Equation Modeling (PLS-SEM) technique was utilized to test the drawn hypotheses by using Smart-PLS 3.0 software. Hence, this study implemented the recommendation of a two-stage approach by Anderson and Gerbing (1988). In the initial stage, the factor structure of the chosen constructs (outer model) was evaluated and confirmed through confirmatory factor analysis (CFA); whereas, in the later stage, the inner model was evaluated through SEM to test the significance of the association among the constructs.

\section{Results and Discussion}

This section elaborates the outcomes of data analysis in the following sequence - assessment of the presence of common method bias in the data, analysis of respondents' demographic profile, assessment of measurement model, and the assessment of structural model with discussion.

Table 2

Sample Profile $(N=252)$

\section{Assessment of Common Method Bias}

As the data was collected from a single source, it is essential to assess if the data is free from common method bias. Therefore, as suggested by Podsakoff and Organ (1986), the Harman's single factor test was applied. The result indicates that $38.68 \%$ of the variance is generated by the first factor, which is lower than the recommended value of $50 \%$; whereas the cumulative variance explained by all the factors is $70.03 \%$, which is higher than the cut-off value of $50 \%$ as suggested by Podsakoff, Mackenzie, Lee, and Podsakoff (2003). These indicates that the collected data are free from common method bias.

\section{Demographic Profile of the Respondents}

The respondents' demographic background suggests that the majority of shoppers were women, which are common in grocery shopping throughout the world and pertinent in the study by Rahman and Noor (2016), within the context of Bangladesh. Although the respondents are from young cohorts, the majority of them (53.6 $\%$ ) are younger in age (23 to 30 years), followed by 24.2 percent who are aged between 36 and 40 years. More than half of the respondents are married and are highly educated within the upper income level. Table 2 records the details of the respondents' demographic profile.

\begin{tabular}{lcrr}
\hline Demographic characteristics & Frequency & Percentage & Cumulative (\%) \\
\hline Gender & & & \\
Male & 120 & 47.6 & 47.6 \\
Female & 132 & 52.4 & 100.0 \\
\hline
\end{tabular}




\begin{tabular}{|c|c|c|c|}
\hline Demographic characteristics & Frequency & Percentage & Cumulative (\%) \\
\hline \multicolumn{4}{|l|}{ Age (in years) } \\
\hline $23-30$ & 135 & 53.6 & 53.6 \\
\hline $30-35$ & 56 & 22.2 & 75.8 \\
\hline $36-40$ & 61 & 24.2 & 100.0 \\
\hline \multicolumn{4}{|l|}{ Education } \\
\hline HSC & 7 & 2.8 & 2.8 \\
\hline Honors/Degree & 112 & 44.4 & 47.2 \\
\hline Master & 130 & 51.6 & 98.8 \\
\hline $\mathrm{PhD}$ & 3 & 1.2 & 100.0 \\
\hline \multicolumn{4}{|l|}{ Marital status } \\
\hline Single & 111 & 44.0 & 44.0 \\
\hline Married & 134 & 53.2 & 97.2 \\
\hline Divorced & 5 & 2.0 & 99.2 \\
\hline Widow & 2 & 0.8 & 100.0 \\
\hline \multicolumn{4}{|l|}{ Monthly income (in BDT*) } \\
\hline Below 40,000 & 37 & 14.7 & 14.7 \\
\hline $40,000-60,000$ & 59 & 23.4 & 38.1 \\
\hline $60,001-80,000$ & 70 & 27.8 & 65.9 \\
\hline $80,001-1,00,000$ & 39 & 15.5 & 81.3 \\
\hline
\end{tabular}

Table 3

Outputs of the Convergent Validity

\begin{tabular}{llcccc}
\hline Variables & Items & Loading & $\begin{array}{c}\text { Cronbach's } \\
\text { Alpha }\end{array}$ & CR & AVE \\
\hline Customer Loyalty & CL1 & 0.710 & 0.805 & 0.861 & 0.511 \\
& CL2 & 0.850 & & & \\
CL3 & 0.752 & & & \\
& CL4 & 0.568 & & \\
CL5 & 0.720 & & \\
& CL6 & 0.656 & & \\
\hline
\end{tabular}




\begin{tabular}{|c|c|c|c|c|c|}
\hline Variables & Items & Loading & $\begin{array}{c}\text { Cronbach's } \\
\text { Alpha }\end{array}$ & CR & AVE \\
\hline \multirow[t]{5}{*}{ Physical Aspect } & PA1 & 0.859 & 0.847 & 0.892 & 0.626 \\
\hline & PA2 & 0.635 & & & \\
\hline & PA3 & 0.785 & & & \\
\hline & PA4 & 0.830 & & & \\
\hline & PA5 & 0.826 & & & \\
\hline \multirow[t]{5}{*}{ Reliability } & REL1 & 0.763 & 0.866 & 0.904 & 0.655 \\
\hline & REL2 & 0.894 & & & \\
\hline & REL3 & 0.736 & & & \\
\hline & REL4 & 0.880 & & & \\
\hline & REL5 & 0.758 & & & \\
\hline \multirow[t]{3}{*}{ Problem Solving } & PS1 & 0.830 & 0.808 & 0.875 & 0.702 \\
\hline & $\mathrm{PS} 2$ & 0.728 & & & \\
\hline & PS3 & 0.943 & & & \\
\hline \multirow[t]{3}{*}{ Policy } & POL1 & 0.830 & 0.851 & 0.910 & 0.771 \\
\hline & POL2 & 0.902 & & & \\
\hline & POL3 & 0.901 & & & \\
\hline \multirow[t]{6}{*}{ Personal Interaction } & PI1 & 0.737 & 0.869 & 0.897 & 0.523 \\
\hline & PI2 & 0.737 & & & \\
\hline & PI3 & 0.849 & & & \\
\hline & PI4 & 0.641 & & & \\
\hline & PI5 & 0.706 & & & \\
\hline & PI6 & 0.792 & & & \\
\hline
\end{tabular}

\section{Assessment of Measurement Model}

The assessment of the measurement model was carried out through convergent validity and discriminant validity to confirm the reliability and validity of the study's constructs. Convergent validity was assessed through factor loading, internal consistency, composite reliability (CR), and AVE (Average Variance Extracted) as suggested by Hair, Hult, Ringle, and Sarstedt (2017). Based on the calculations from Table 3, the data reveals that factor loading of all items from the six constructs are more than 0.60 (except CL4), Cronbach's alpha values of each construct exceed the threshold level of 0.7, CR values are above 0.70 , and AVE of all constructs are greater than 0.50 of the recommended threshold value. Thus, all these outcomes exhibit the presence of convergent validity of the outer model. 
Discriminant validity of the measurement model was justified by both the Fornell and Larcker (1981) criterion and the heterotrait-monotrait ratio of correlation (HTMT) that is based on the multitrait-multimethod matrix recommended by Henseler, Ringle, and Sarstedt (2015). Data from Table 4 illustrates that the square roots of AVE of all constructs are higher than the off-diagonal correlation values in each row and column that corresponds to them. Hence, the discriminant validity of the measurement model is achieved (Fornell \& Larcker, 1981). Moreover, as depicted in Table 5, the HTMT values are less than the suggested cut-off value of 0.85 , indicating that discrimination is confirmed in the validity of the measurement model (Kline, 2015).

Table 4

Discriminant Validity (Fornell and Larcker Criterion)

\begin{tabular}{llcccccc}
\hline & & 1 & 2 & 3 & 4 & 5 & 6 \\
\hline 1 & Customer Loyalty & $\mathbf{0 . 7 1 5}$ & & & & & \\
2 & Physical Aspect & 0.648 & $\mathbf{0 . 7 9 1}$ & & & & \\
3 & Reliability & 0.676 & 0.570 & $\mathbf{0 . 8 0 9}$ & & & \\
4 & Problem Solving & 0.132 & 0.031 & 0.094 & $\mathbf{0 . 8 3 8}$ & & \\
5 & Policy & 0.619 & 0.599 & 0.440 & 0.017 & $\mathbf{0 . 8 7 8}$ & \\
6 & Personal Interaction & 0.663 & 0.607 & 0.725 & 0.017 & 0.404 & $\mathbf{0 . 7 2 4}$ \\
\hline
\end{tabular}

Note: Below the diagonal are the values of correlation between constructs; whereas the bold values of the diagonal are the square root of Average Variance Extracted (AVE) of the constructs indicating the highest in any row or column.

Table 5

Discriminant Validity (HTMT)

\begin{tabular}{llcccccc}
\hline & & 1 & 2 & 3 & 4 & 5 & 6 \\
\hline 1 & Customer Loyalty & & & & & \\
2 & Physical Aspect & 0.767 & & & & \\
3 & Reliability & 0.790 & 0.671 & & & \\
4 & Problem Solving & 0.161 & 0.076 & 0.093 & & \\
5 & Policy & 0.731 & 0.704 & 0.504 & 0.106 & \\
6 & Personal Interaction & 0.767 & 0.700 & 0.829 & 0.107 & 0.472 & \\
\hline
\end{tabular}

Note: Heterotrait-Monotrait Ratio (HTMT) discriminate at $($ HTMT <0.85) 


\section{Assessment of Structural Model}

Before the evaluation of the structural model, it was suggested by scholars to examine the presence of multicollinearity among the exogenous variables through VIF (Variance Inflation Factor). Table 6 illustrates that the VIF values of all the predictors (ranging from 1.015 to 2.400) are less than the cut-off value of 3.3 that was recommended by Kock and Lynn (2012), indicating that the structural model is free from multicollinearity issue.

Table 6

Collinearity Assessment (VIF)
As recommended by Hair et al. (2017), the basic criteria for evaluating structural models are by analyzing the $\mathrm{R}^{2}$ value (coefficient of determination), beta value, generated t-values based on bootstrapping procedure (with sample of 5000), $\mathrm{f}^{2}$ values (measure of the effect sizes), and the $\mathrm{Q}^{2}$ value (measure of the predictive relevance). The outputs from the structural model are shown in Figure 2 and Table 7.

\begin{tabular}{lcc}
\hline Predictors & Criterion Variable & Inner VIF Values \\
\hline Physical Aspect & Customer Loyalty & 2.123 \\
Reliability & Customer Loyalty & 2.308 \\
Problem Solving & Customer Loyalty & 1.015 \\
Policy & Customer Loyalty & 1.598 \\
Personal Interaction & Customer Loyalty & 2.400 \\
\hline
\end{tabular}

Table 7

Outcomes of the Structural Model

\begin{tabular}{|c|c|c|c|c|c|c|c|c|c|c|}
\hline Hs & Relationship & Beta & SE & t-value & Decision & $\mathbf{R}^{2}$ & $\mathbf{f}^{2}$ & $\mathbf{Q}^{2}$ & $\begin{array}{c}95 \% \\
\text { CI LL }\end{array}$ & $\begin{array}{c}95 \% \\
\text { CI } \\
\text { UL }\end{array}$ \\
\hline H1 & $\begin{array}{l}\text { Physical } \\
\text { Aspect -> } \\
\text { Customer } \\
\text { Loyalty }\end{array}$ & 0.162 & 0.058 & $2.808^{* *}$ & Supported & 0.648 & 0.035 & 0.307 & 0.064 & 0.254 \\
\hline $\mathrm{H} 2$ & $\begin{array}{l}\text { Reliability } \\
->\text { Customer } \\
\text { Loyalty }\end{array}$ & 0.257 & 0.054 & $4.779^{* * *}$ & Supported & & 0.081 & & 0.165 & 0.343 \\
\hline $\mathrm{H} 3$ & $\begin{array}{l}\text { Problem } \\
\text { Solving -> } \\
\text { Customer } \\
\text { Loyalty }\end{array}$ & 0.094 & 0.039 & $2.385^{* *}$ & Supported & & 0.025 & & 0.016 & 0.148 \\
\hline
\end{tabular}

(continued) 


\begin{tabular}{|c|c|c|c|c|c|c|c|c|c|c|}
\hline Hs & Relationship & Beta & SE & t-value & Decision & $\mathbf{R}^{2}$ & $\mathbf{f}^{2}$ & $\mathbf{Q}^{2}$ & $\begin{array}{c}95 \% \\
\text { CI LL }\end{array}$ & $\begin{array}{c}95 \% \\
\text { CI } \\
\text { UL }\end{array}$ \\
\hline $\mathrm{H} 4$ & $\begin{array}{l}\text { Policy -> } \\
\text { Customer } \\
\text { Loyalty }\end{array}$ & 0.305 & 0.053 & $5.802^{* * *}$ & Supported & & 0.166 & & 0.220 & 0.393 \\
\hline H5 & $\begin{array}{l}\text { Personal } \\
\text { Interaction } \\
\text {-> Customer } \\
\text { Loyalty }\end{array}$ & 0.253 & 0.051 & $4.935^{* * *}$ & Supported & & 0.076 & & 0.166 & 0.334 \\
\hline
\end{tabular}

Note: ${ }^{* *} \mathrm{p}<0.01 ;{ }^{* * * *} \mathrm{p}<0.001$

The analysis outputs indicate that customer loyalty is significantly influenced by all the predictors of the research model. This suggests that physical aspect $(\beta=0.160, \mathrm{t}=2.808$, and $\mathrm{p}$ $<0.01)$, reliability $(\beta=0.257, \mathrm{t}=4.779$, and $\mathrm{p}<$ $0.001)$, problem solving $(\beta=0.095, \mathrm{t}=2.385$, and $\mathrm{p}<0.01)$, policy $(\beta=0.305, \mathrm{t}=5.802$, and $\mathrm{p}<0.001)$, and personal interaction $(\beta=0.256$, $\mathrm{t}=4.935$, and $\mathrm{p}<0.001)$ have a significant relationship with customer loyalty. Hence, the outputs from the structural model support the hypotheses ( $\mathrm{H} 1, \mathrm{H} 2, \mathrm{H} 3, \mathrm{H} 4$, and $\mathrm{H} 5)$ of the study (Table 7). Furthermore, in determining the loyalty of Gen Y in superstores, the result of the path model suggest that all the dimensions of the RSQS model has significant and positive influence on customer loyalty.

The $\mathrm{R}^{2}$ value of customer loyalty is 0.648 , which is greater than the threshold value of 0.26 as recommended by Cohen (1988). This demonstrates that the model is significant, and further implies that 64.8 percent of the variation in customer loyalty can be explained by physical aspect, reliability, problem solving, policy, and personal interaction.

Moreover, the change in $\mathrm{R}^{2}$ value has to be examined to obtain the value of $\mathrm{f}^{2}$ (effect size)
(Hair et al., 2017). Typically, the method is carried out by observing the change in $\mathrm{R}^{2}$ as a result of omitting a particular exogenous construct from the model. This method is used to investigate the omitted endogenous variable, whether it has a substantive impact on the outcome construct of the model. Table 7 presents the value of $\mathrm{f}^{2}$ for the model of this study. The effect size of 0.02 , 0.15 , and 0.35 represent small, medium, and large effect respectively, as suggested by Cohen (1988). The results indicate that policy has a large effect; whereas, the remaining has small effect on customer loyalty. Other than that, this study investigates the predictive relevance of the model by applying the blindfolding procedure (Table 7) as recommended by Henseler, Ringle, and Sinkovics (2009). The model is suggested to have a predictive relevance for a specific endogenous construct if the value of $\mathrm{Q}^{2}$ of that endogenous construct is greater than zero (0) (Hair et al., 2017; Rahman, Taghizadeh, Ramayah, \& Alam, 2017). The $\mathrm{Q}^{2}$ values of $0.02,0.15$, and 0.35 respectively, represent small, medium, and large predictive relevance of exogenous construct(s) for a particular endogenous construct (Hair et al., 2017). The results indicate that the $Q^{2}$ value for customer loyalty $\left(\mathrm{Q}^{2}=0.307\right)$ is greater than zero (0), which asserts that the extent of predictive relevance of the model is medium. 


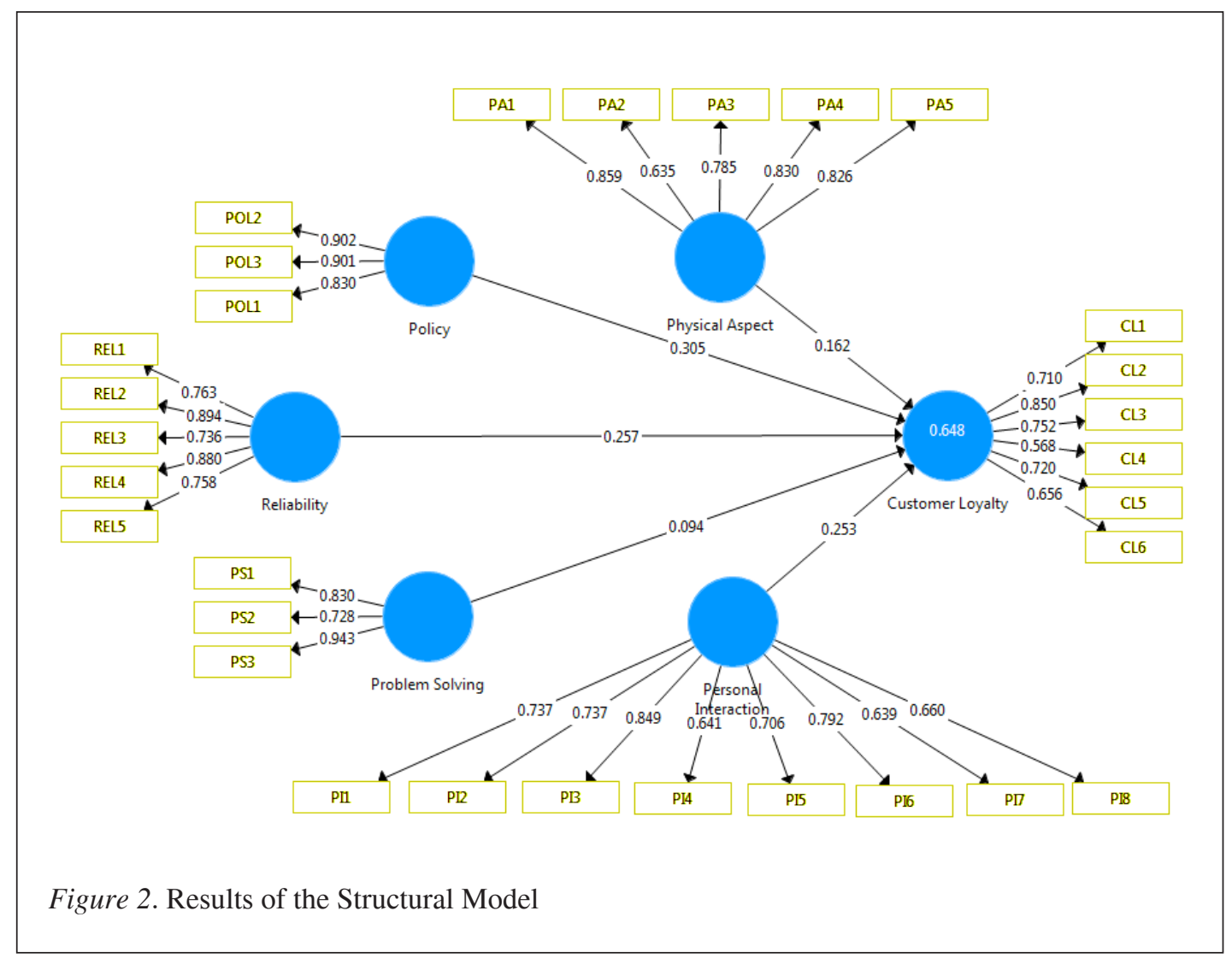

\section{Conclusion}

This study examined the relationship between service quality dimensions of RSQS and customer loyalty of Gen $\mathrm{Y}$ in the platform of superstore retailing in Bangladesh. The results indicated that all the retail service quality dimensions, which are physical aspects, reliability, problem solving, policy, and personal interaction have had a significantly positive effect on impacting loyalty of Gen Y. Among these dimensions, store policy has exerted the most influence on the loyalty of Gen Y, followed by reliability.

This study has made several academic and practical contributions. Firstly, this study investigated the influence of RSQS dimensions on customer loyalty of a particular generational cohort, namely Gen Y. From the research outputs, it has been deduced that in retaining young customers, various aspects of service quality has played vital roles in affecting loyalty, and subsequently enriched the domain of service marketing. Secondly, this study confirmed the applicability of the CMR theory developed by Lazarus (1991) and suggested by Sivapalan and Jebarajakirthy (2017) to establish the relationship between RSQS dimensions and customer loyalty. Thirdly, this study incorporated for the first time, the RSQS instrument to measure service quality in the context of retail superstore in Bangladesh, hence addressing the contextual gap in literature. Lastly, this study provided a practical avenue for retail practitioners for gaining an understanding on the potential lucrative opportunity provided by Gen Y to the retail market. Retailers will be able to gauge customer loyalty by ensuring the right service qualities are practised, such as developing concrete guiding policies and delivering reliable services. 
There are limitation in this study. This study focused on the loyalty behavior of Gen Y and examined the influence of RSQS dimensions on their loyalty. However, the application of the RSQS instrument is still questionable on whether it can be generalized for the entire retail industry and population of Bangladesh. The data gathering approach of this study was cross-sectional. Due to rapid change in the retail environment, consumers' perceptions and evaluations about superstore quality are also subjected to change. Thus, collecting data with a longitudinal approach could make the results more realistic and substantial, with regards to the holistic view of the retail market.

This study provided some avenues for future research. Firstly, in addition to RSQS dimensions, future researchers can consider other antecedents of customer loyalty such as customer engagement and experience that might present more variability in identifying other influences on customer loyalty for superstores. Secondly, based on literature review, researchers can identify other moderating variables to justify the strength of the relationship between RSQS dimensions and customer loyalty. Finally, the existing model can be extended by incorporating one or more mediating variables in direct relationship between the factors of RSQS and loyalty of Gen Y.

\section{References}

Adam, S., Tengeh, R. K., \& Cupido, C. (2018). An assessment of youth's perception of the service quality of large food retailers in South Africa. Journal of Business and Retail Management Research, 12(3), 241-253.

Altinbasak-Farina, I., \& Guleryuz-Turkel, G. (2015). Identifying the needs of Gen $\mathrm{Y}$ by exploring their value systems: A qualitative study. International Journal of Trade, Economics and Finance, 6(6), 290-296.
Alwin, D. F., \& McCammon, R. J. (2003). Generations, cohorts, and social change. In Handbook of the life course (pp. 2349). Springer, Boston, MA.

Amorim, M., \& Bashashi Saghezchi, F. (2014). An investigation of service quality assessments across retail formats. International Journal of Quality and Service Sciences, 6(2/3), 221-236.

Anderson, J. C., \& Gerbing, D. W. (1988). Structural equation modeling in practice: A review and recommended two-step approach. Psychological Bulletin, 103(3), 411-423. doi. org/10.1037/0033-2909.103.3.411

Arif, M. Z. U. (2013). A study on increasing establishment of superstores in Bangladesh with special reference to Dhaka City. Anveshak International Journal of Management (AIJM), 2(1), 9-34.

Babakus, E., \& Boller, G. W. (1992). An empirical assessment of the SERVQUAL scale. Journal of Business Research, 24(3), 253-268.

Bachmann, D. (2008, December 26). Supermarkets on the rise. The Daily Star. Retrieved from https://www. thedailystar.net/news-detail-68728

Bapat, D. (2017). Exploring the antecedents of loyalty in the context of multi-channel banking. International Journal of Bank Marketing, 35(2), 174-186.

Beneke, J., Hayworth, C., Hobson, R., \& Mia, Z. (2012). Examining the effect of retail service quality dimensions on customer satisfaction and loyalty: The case of the supermarket shopper. Acta Commercii, 12(1), 27-43.

Bhat, I. H. (2016). Validating a retail service quality instrument in grocery specialty stores. International Journal of Information, Business and Management, 8(2), 205-217.

Bilgihan, A. (2016). Gen Y customer loyalty in online shopping: An integrated model of trust, user experience and 
branding. Computers in Human Behavior, 61, 103-113.

Boshoff, C., \& Terblanche, N. S. (1997). Measuring retail service quality: a replication study. South African Journal of Business Management, 28(4), 123128.

Bouman, M., \& Van der Wiele, T. (1992). Measuring service quality in the car service industry: Building and testing an instrument. International Journal of Service Industry Management, 3(4), 4-16.

Brady, M. K., \& Cronin Jr, J. J. (2001). Some new thoughts on conceptualizing perceived service quality: a hierarchical approach. Journal of Marketing, 65(3), 34-49.

Brady, M. K., \& Robertson, C. J. (2001). Searching for a consensus on the antecedent role of service quality and satisfaction: an exploratory crossnational study. Journal of Business Research, 51(1), 53-60.

Byrne, B. M. (2010). Structural equation modeling with AMOS: Basic concepts, applications, and programming ( $\left.2^{\text {nd }} e d.\right)$. New York: Routledge Academy.

Carman, J. M. (1990). Consumer perceptions of service quality: An assessment of the SERVQUAL dimensions. Journal of Retailing, 66(1), 33-55.

Caruana, A. (2002). Service loyalty: The effects of service quality and the mediating role of customer satisfaction. European Journal of Marketing, 36(7/8), 811-828.

Chahal, H., \& Rani, A. (2017). How trust moderates social media engagement and brand equity. Journal of Research in Interactive Marketing, 11(3), 312-335.

Cham, T. H., Ng, C. K. Y., Lim, Y. M., \& Cheng, B. L. (2018). Factors influencing clothing interest and purchase intention: a study of Generation $\mathrm{Y}$ consumers in Malaysia. The International Review of Retail, Distribution and Consumer Research, 28(2), 174-189.
Chang, Y. H., \& Yeh, C. H. (2017). Corporate social responsibility and customer loyalty in intercity bus services. Transport Policy, 59, 38-45.

Chuah, S. H. W., Marimuthu, M., Kandampully, J., \& Bilgihan, A. (2017). What drives Gen Y loyalty? Understanding the mediated moderating roles of switching costs and alternative attractiveness in the value-satisfaction-loyalty chain. Journal of Retailing and Consumer Services, 36, 124-136.

CIA Report. (2017). The world fact book Bangladesh. The World Fact book. Retrieved from https://www.cia.gov/ library/publications/the-world-factbook/ geos/bg.html

Cohen, J. (1988). Statistical power analysis for the behavioral sciences (2nd ed.). Hilldale NJ: Erlbaum: Routledge.

Cronin Jr, J. J., \& Taylor, S. A. (1992). Measuring service quality: a reexamination and extension. The Journal of Marketing, 56, 55-68.

Dabholkar, P. A., Thorpe, D. I., \& Rentz, J. O. (1996). A measure of service quality for retail stores: scale development and validation. Journal of the Academy of Marketing Science, 24(1), 3-16.

Dalla Pozza, I., Heitz-Spahn, S., \& Texier, L. (2017). Generation Y multichannel behaviour for complex services: the need for human contact embodied through a distance relationship. Journal of Strategic Marketing, 25(3), 226-239.

Das, A., Kumar, V., \& Saha, G. C. (2010). Retail service quality in context of CIS countries. International Journal of Quality \& Reliability Management, 27(6), 658-683.

Deb, M., \& Lomo-David, E. (2014). Evaluation of retail service quality using analytic hierarchy process. International Journal of Retail \& Distribution Management, 42(6), 521-541.

De Leaniz, P. M. G., \& del Bosque Rodríguez, I. R. (2016). Corporate image and reputation 
as drivers of customer loyalty. Corporate Reputation Review, 19(2), 166-178.

Dick, A. S., \& Basu, K. (1994). Customer loyalty: toward an integrated conceptual framework. Journal of the Academy of Marketing Science, 22(2), 99-113.

El-Adly, M. I. (2018). Modelling the relationship between hotel perceived value, customer satisfaction, and customer loyalty. Journal of Retailing and Consumer Services. (just accepted), 00-00. https://doi. org/10.1016/j.jretconser.2018.07.007

Finn, D.W. \& Lamb, C.W. (1991). An evaluation of the SERVQUAL scale in a retailing setting. In Holman, R.H. and Solomon, M.R. (Eds), Advances in Consumer Research, Association for Consumer Research, Provo, UT, 483-490.

Fornell, C., \& Larcker, D. F. (1981). Structural equation models with unobservable variables and measurement error. Journal of Marketing Research, 18(1), 39-50.

Fyall, A., Leask, A., Barron, P., \& Ladkin, A. (2017). Managing Asian attractions, Generation Y and face. Journal of Hospitality and Tourism Management, 32, 35-44.

Gagliano, K. B., \& Hathcote, J. (1994). Customer expectations and perceptions of service quality in retail apparel specialty stores. Journal of Services Marketing, 8(1), 60-69.

Gain Report. (2013). The Food Retail Sector in Bangladesh, 1-9. Retrieved from https:// gain.fas.usda.gov/Recent $\% 20$ GAIN $\% 20$ Publications/The $\% 20$ Food $\% 20$ Retail\%20Sector\%20in\%20Bangladesh_ New\%20Delhi_Bangladesh_7-3-2013. pdf

Gong, T., \& Yi, Y. (2018). The effect of service quality on customer satisfaction, loyalty, and happiness in five Asian countries. Psychology \& Marketing, 35(6), 427-442.

Grönroos, C. (1984). A service quality model and its marketing implications. European Journal of Marketing, 18(4), 36-44.
Grosso, M., Castaldo, S., \& Grewal, A. (2018). How store attributes impact shoppers' loyalty in emerging countries: An investigation in the Indian retail sector. Journal of Retailing and Consumer Services, 40, 117-124.

Ha, N. T., Minh, N. H., Anh, P. C., \& Matsui, Y. (2014). The relationship between service quality and customer loyalty in specialty supermarket - Empirical evidence in Vietnam. International Journal of Business and Economics Research, 3(5), 178-186.

Ha, N. T., Minh, N. H., Anh, P. C., \& Matsui, Y. (2015). Retailer Service Quality and Customer Loyalty: Empirical Evidence in Vietnam. Asian Social Science, 11(4), 90-101.

Hair, J. F., Hult, G. T. M., Ringle, C. M., \& Sarstedt, M. (2017). A Primer on Partial Least Squares Structural Equation Modeling. California: Thousand Oaks: Sage.

Hegner-Kakar, A. K., Richter, N. F., \& Ringle, C. M. (2018). The customer loyalty cascade and its impact on profitability in financial services. In Partial least squares structural equation modeling (pp. 53-75). Springer, Cham.

Henseler, J., Ringle, C., \& Sinkovics, R. (2009). The use of partial least squares path modeling in international marketing. Advances in International Marketing (AIM), 20, 277-320.

Henseler, J., Ringle, C. M., \& Sarstedt, M. (2015). A new criterion for assessing discriminant validity in variance-based structural equation modeling. Journal of the Academy of Marketing Science, 43(1), 115-135.

Inglehart, R. (1977). The silent revolution: Changing values and political styles among Western publics. Princeton, NJ: Princeton University Press.

Jain, P., \& Aggarwal, V. S. (2016). Validating RSQS in organised electronics retail market in India. BVIMSR's Journal of Management Research, 8(2), 128-136. 
Jain, P., \& Aggarwal, V. S. (2018). Developing a servicequality scale in context of organized grocery retail of India. Management Decision. 56(9), 1969-1990.

Kajenthiran, K. (2018). An Empirical Investigation on Retail Service Quality and Its Impact on Customer Loyalty in the Supermarkets in Jaffna District, Sri Lanka. Advances in Management and Applied Economics, 8(1), 17-36.

Kamran-Disfani, O., Mantrala, M. K., IzquierdoYusta, A., \& Martínez-Ruiz, M. P. (2017). The impact of retail store format on the satisfaction-loyalty link: An empirical investigation. Journal of Business Research, 77, 14-22.

Kasiri, L. A., Cheng, K. T. G., Sambasivan, M., \& Sidin, S. M. (2017). Integration of standardization and customization: Impact on service quality, customer satisfaction, and loyalty. Journal of Retailing and Consumer Services, 35, 91-97.

Kim, S., \& Jin, B. (2002). Validating the retail service quality scale for US and Korean customers of discount stores: an exploratory study. Journal of Services Marketing, 16(3), 223-237.

Kline, R. B. (2015). Principles and practice of structural equation modeling. New York: Guilford publications.

Knittel, Z., Beurer, K., \& Berndt, A. (2016). Brand avoidance among Generation Y consumers. Qualitative Market Research: An International Journal, 19(1), 27-43.

Kock, N., \& Lynn, G. (2012). Lateral collinearity and misleading results in variance-based SEM: An illustration and recommendations. Journal of the Association for Information Systems, 13(7), 546-580.

Lazarus, R. S. (1991). Progress on a cognitivemotivational-relational theory of emotion. American Psychologist, 46(8), 819-834.

Lee, L. W., Tang, Y., Yip, L. S., \& Sharma, P. (2018). Managing customer relationships in the emerging markets-guanxi as a driver of Chinese customer loyalty. Journal of Business Research, 86, 356-365.

Li, W., Yu, S., Pei, H., Zhao, C., \& Tian, B. (2017). A hybrid approach based on fuzzy AHP and 2-tuple fuzzy linguistic method for evaluation in-flight service quality. Journal of Air Transport Management, 60, 49-64.

Lissitsa, S., \& Kol, O. (2016). Generation X vs. Generation Y-A decade of online shopping. Journal of Retailing and Consumer Services, 31, 304-312.

Maggioni, I. (2016). What drives customer loyalty in grocery retail? Exploring shoppers' perceptions through associative networks. Journal of Retailing and Consumer Services, 33, 120-126.

Makanyeza, C., \& Chikazhe, L. (2017). Mediators of the relationship between service quality and customer loyalty: Evidence from the banking sector in Zimbabwe. International Journal of Bank Marketing, 35(3), 540-556.

Marcoulides, G. A., \& Saunders, C. (2006). Editor's comments: PLS: a silver bullet? MIS Quarterly, 30(2), 3-9.

Meng, J., Summey, J. H., Herndon, N. C., \& Kwong, K. K. (2009). Some retail service quality expectations of Chinese shoppers. International Journal of Market Research, 51(6), 773-796.

Mohd-Ramly, S., \& Omar, N. A. (2017). Exploring the influence of store attributes on customer experience and customer engagement. International Journal of Retail \& Distribution Management, 45(11), 1138-1158.

Monthly Business Review. (2017). Supermarkets: new trend in urban shopping - reshaping modern retail trade, 13(10), 8-15. Retrieved from http://idlc.com/public/documents/ mbr/17/Monthly\%20Business \% 20 Review\%20-October\%202017.pdf

Nadiri, H., \& Tümer, M. (2009). Retail services quality and behavioural intentions: an empirical application of the retail service 
quality scale in Northern Cyprus. $E \& M$ Econimics and Management, 12(2), 127139.

Ngobo, P. V. (2017). The trajectory of customer loyalty: an empirical test of Dick and Basu's loyalty framework. Journal of the Academy of Marketing Science, 45(2), 229-250.

Nguyen, T. N., Nguyen, H. L., Cao, T. K., \& Phan, T. T. H. (2016). The Influence of Service Quality on Customer Loyalty Intentions: A Study in the Vietnam Retail Sector. Asian Social Science, 12(2), 112119.

Nyadzayo, M. W., \& Khajehzadeh, S. (2016). The antecedents of customer loyalty: A moderated mediation model of customer relationship management quality and brand image. Journal of Retailing and Consumer Services, 30, 262-270.

Oliver, R. L. (1999). Whence consumer loyalty? Journal of Marketing, 63, 33-44.

Orel, F. D., \& Kara, A. (2014). Supermarket self-checkout service quality, customer satisfaction, and loyalty: Empirical evidence from an emerging market. Journal of Retailing and Consumer Services, 21(2), 118-129.

Parasuraman, A., Zeithaml, V. A., \& Berry, L. L. (1985). A conceptual model of service quality and its implications for future research. Journal of Marketing, 49, 4150.

Parasuraman, A., Zeithaml, V. A., \& Berry, L. L. (1988). SERVQUAL: A multipleitem scale for measuring consumer perception of service quality. Journal of Retailing, 64(1), 12-40.

Parment, A. (2013). Generation Y vs. Baby Boomers: Shopping behavior, buyer involvement and implications for retailing. Journal of Retailing and Consumer Services, 20(2), 189-199.

Podsakoff, P. M., MacKenzie, S. B., Lee, J. Y., \& Podsakoff, N. P. (2003). Common method biases in behavioral research: A critical review of the literature and recommended remedies. Journal of Applied Psychology, 88(5), 879-903.

Podsakoff, P. M., \& Organ, D. W. (1986). Self-reports in organizational research: Problems and prospects. Journal of Management, 12(4), 531-544.

Prentice, C., Wang, X., \& Lin, X. (2018). An organic approach to customer engagement and loyalty. Journal of Computer Information Systems, 1-10. (just accepted), 00-00. https://doi.org/10.1080/08874417.2018.1 485528

Quintal, V., Phau, I., Sims, D., \& Cheah, I. (2016). Factors influencing generation Y's purchase intentions of prototypical versus me-too brands. Journal of Retailing and Consumer Services, 30, 175-183.

Rahman, K. M., \& Noor, N. A. M. (2016). Exploring Organic Food Purchase Intention in Bangladesh: An Evaluation by Using the Theory of Planned Behavior. International Business Management, 10(18), 4292-4300.

Rahman, S. A., Taghizadeh, S. K., Ramayah, T., \& Alam, M. M. D. (2017). Technology acceptance among microentrepreneurs in marginalized social strata: The case of social innovation in Bangladesh. Technological Forecasting and Social Change, 118, 236-245.

Reardon, T., Timmer, P., \& Berdegue, J. (2004). The rapid rise of supermarkets in developing countries: induced organizational, institutional, and technological change in agrifood systems. Electronic Journal of Agricultural and Development Economics, 1(2), 168-183.

Shamsher, R. (2016). Store image and its impact on consumer behaviour. Elk Asia Pacific Journal of Marketing and Retail Management, 7(2), 1-27.

Singh, A. (2012). Impact of perceived service quality on customer loyalty intentions in retail outlets. European Journal of Business and Management, 4(21), 138149. 
Siu, N. Y., \& Cheung, J. T. (2001). A measure of retail service quality. Marketing Intelligence \& Planning, 19(2), 88-96.

Sivapalan, A., \& Jebarajakirthy, C. (2017). An application of retailing service quality practices influencing customer loyalty toward retailers. Marketing Intelligence \& Planning, 35(7), 842-857.

Soares, R. R., Zhang, T. T., Proença, J., \& Kandampully, J. (2017). Why are generation Y consumers the most likely to complain and repurchase? Journal of Service Management, 28(3), 520-540.

Sundarapandiyan, N., Duraiarasi, B., Babu, S., \& Prabakaran, K. (2015). A research on the influence of media advertisements in the purchasing decisions of Generation $Y$ in Penang Malaysia. International Journal of Sciences: Basic and Applied Research (IJSBAR), 21(1), 192-222.

Tangsupwattana, W., \& Liu, X. (2017). Symbolic consumption and Generation Y consumers: Evidence from Thailand. Asia Pacific Journal of Marketing and Logistics, 29(5), 917-932.

The Daily Star. (Feb 07, 2016). Right strategy key to e-commerce growth: Retailers. Retrieved from http://epaper.thedailystar.net/index. php?opt $=$ view $\&$ page $=17 \&$ date $=2016$ 02-07
Ushantha, R. A. C., Wijeratne, A. W., \& Achchuthan, S. (2014). An assessment of retail service quality: An empirical study of the RSQS in Sri Lankan supermarkets. Developing Country Studies, 4(3), 78-90.

Vargo, S. L., \& Lusch, R. F. (2004). Evolving to a new dominant logic for marketing. Journal of Marketing, 68(1), 1-17.

Vazquez, R., Rodríguez-Del Bosque, I. A., Díaz, A. M., \& Ruiz, A. V. (2001). Service quality in supermarket retailing: Identifying critical service experiences. Journal of Retailing and Consumer Services, 8(1), 1-14.

Wong, A., \& Sohal, A. (2003). Service quality and customer loyalty perspectives on two levels of retail relationships. Journal of Services Marketing, 17(5), 495-513.

Yeap Ai Leen, J., \& Ramayah, T. (2011). Validation of the RSQS in apparel specialty stores. Measuring Business Excellence, 15(3), 16-18.

Yuen, E. F., \& Chan, S. S. (2010). The effect of retail service quality and product quality on customer loyalty. Journal of Database Marketing \& Customer Strategy Management, 17(3-4), 222-240. 